\title{
Identifying Common Errors of the First Graders in the Writing of Vertical Numbers
}

\author{
Zeynep Doğan ${ }^{1, *}$ \\ ${ }^{1}$ Faculty of Education, Yildiz Technical University, İstanbul, Turkey \\ *Correspondence: Faculty of Education, Yildiz Technical University, İstanbul, Turkey. Tel: 90-212-383-4856. E-mail: \\ zeynepyildiz.2005@hotmail.com
}

Received: October 20, 2018

Accepted: November 20, 2018 Online Published: February 20, 2019

doi:10.5430/wje.v9n1p229

URL: https://doi.org/10.5430/wje.v9n1p229

\begin{abstract}
The aim of the study is to investigate the errors that first grade students have made in their writing of vertical numbers which have just been applied by removing cursive writing. Considering the aim of the study, vertical number writing styles of the first-grade students in primary school were analyzed. The sample of the study consists of 116 students who are studying in the first grade of primary school. The study was defined as a case study. A data collection tool was developed for determining the mistakes that students made while writing the vertical numbers in line with the aim of the research. Through the data collection tool, all numbers from 0 to 9 are given as written statements and it is required to write the numbers in the spaces left under them. The results obtained from the analysis of the data include the existing types of errors that are relevant to the number writing in the students after the first literacy teaching processes. According to the results of the research, writing the numbers oblique, vertical-horizontal-diagonal straight lines are drawn in a curvilinear style, curvilinear and circular lines are distorted, numbers are not aligned in the direction of writing, and some numbers are written in reverse have been seen as the most common errors. In accordance with the types of errors identified in the research, it is thought that the emphasis on dictation studies to increase the awareness of students will decrease these types of errors and their frequency. It is also stated that it is important to diversify the related studies as much as possible, taking into consideration the individual differences of the students.
\end{abstract}

Keywords: vertical numbers, the first grade in primary school, writing errors

\section{Introduction}

\subsection{The Statement of the Problem}

Writing is defined as the ability to produce the symbols and signs that are necessary to express our thoughts; text is defined as the forms of words and sentences in the spoken language that are determined on paper with some symbolic shapes and drawings (Akyol, 2001; Celenk, 2007). Although these definitions are not directly addressed, the writing of numbers has an important role in primary school education in relation to mathematics teaching. Just as we use symbols that are called letters to spell words in speech, we can define numbers as symbols which are used to write and display numbers as well. Therefore, the most important symbols that we use to write the language of Mathematics are numbers. The primary Mathematics curriculum consists of four learning areas: Numbers and Operations, Geometry, Measurement and Data processing. While all learning areas are provided at each class level, some sub-learning areas are activated after a specific class. Natural numbers in the learning area of Numbers and Operations and the acquisitions of sub-learning area start with the teaching of numbers, it is aimed to learn larger numbers and steps as the class level increases (MEB, 2018a). Thus, the teaching of numbers is also the basis of primary school mathematics teaching. When studying the literature, neither the teaching of the first reading and writing nor the teaching mathematics were found to be a study on the formal teaching of numbers. Therefore, it emerges that there is a need to investigate the errors that the first-grade students make while writing the numbers in learning processes of first reading-writing and mathematics. In this respect, the aim of the study was determined as the investigation of the errors made by the first-grade students in primary school while writing the vertical numbers. By conducting the study, it is aimed to determine the errors related to the number and the letter writing when the writing skills of students from $2 \mathrm{nd}$, 3rd and 4th grade in primary school are analyzed. It is thought that the study can 
prevent the potential mistakes of students when their primary school teachers who have just started or will start their profession carry out the process of reading-writing with their students.

\section{Method}

\subsection{Research Design}

Case study from qualitative research methods was used in the study. According to Stake (1995) and Yin $(2009,2012)$, case study is a research design in which researchers analyze a situation, often a program, event, action, process, one or more individuals in depth. In the study, research design was determined as case study as the vertical numbers of the first graders in primary school were examined and their learning errors were tried to be analyzed.

\subsection{Study Group}

The first-grade students in primary school are expected to acquire literacy skills in first grade. For this reason, the study was conducted with the first graders. The study group of the research is composed of 116 students who are studying in the first grade of a public school in Istanbul. Thus, it is thought that a positive contribution can be made to the process of determining the errors in the number writing process at the end of the first grade and to the process of gaining the skills of reading and writing.

\subsection{Data Collection Instrument}

The data collection tool used in the research was developed by the researchers in order to detect the typing mistakes.

As the data collection tool for numbers was developed, all numbers from 0 to 9 were written in an appropriate format on A4, and it was required to write the numbers in the spaces left under these written expressions. After the data collection tools were developed, three classroom teachers and three experts were consulted. As a result of the opinions of the experts and teachers, data collection tools were finalized and ready for implementation. Figure 1 shows the visual example of a part of the data collection tool.

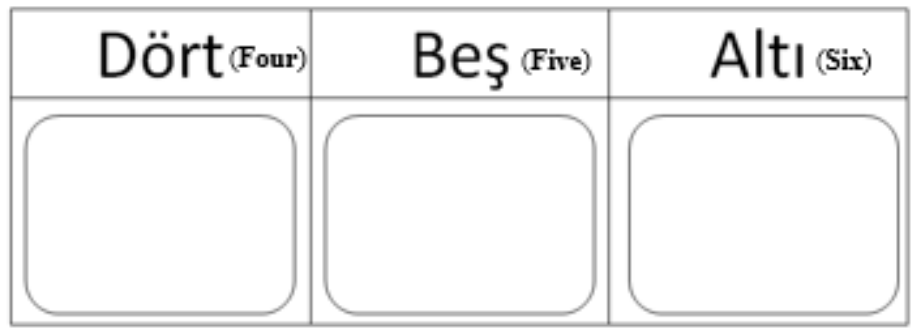

Figure 1. A Part from the Data Collection Tool

\subsection{Data Collection and Analysis of Data}

The data collection tool for the numbers was distributed to the students and they were asked to write the corresponding numbers to the spaces left under the written expressions. After the data collection tools were distributed to students, they were asked to fill in the gaps appropriately. In the process of analysis, the data collection tools applied were examined in general, and papers which were unreadable, which were not mostly filled, or which were filled with irrelevant content were excluded from the evaluation.

Classifications were made concerning common errors by carefully reviewing the data obtained and comparing the numbers with their correct writing style (Figure 2). Figure 2 shows images of the correct type of number (TTKB, 2017). 


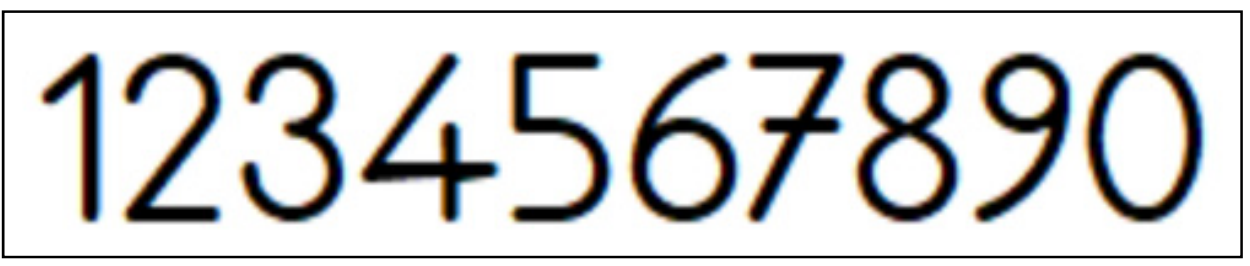

Figure 2. Correct Writing Type of Vertical Numbers

\section{Results}

In the According to the findings obtained from the research, the types of errors realized for each figure were determined and a table was created for each figure. The representations of error types made and the sample images corresponding to these statements are presented in these tables.

Table 1. Types of Common Errors and Sample Visuals from These Errors Which Were Made about the Number "1"

Errors in writing of the number 1
Placing horizontal line below
Drawing the number with oblique lines
The diagonal line at the tip is too long/short
Writing oblique
Bhe top tip is not sharp


Table 2. Types of Common Errors and Sample Visuals from These Errors Which Were Made about the Number " 2 "

\begin{tabular}{l} 
Errors in writing of the number 2 \\
\hline The bottom horizontal line is not parallel to the \\
floor / sloped up / down
\end{tabular}
floor / sloped up / down

The bottom horizontal line is too long / short
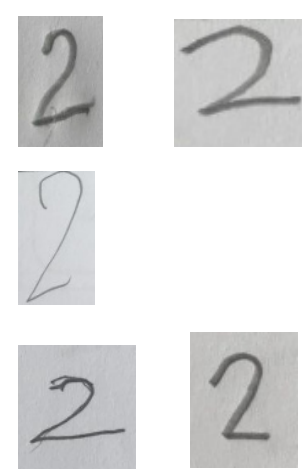

The top tip is very long/short
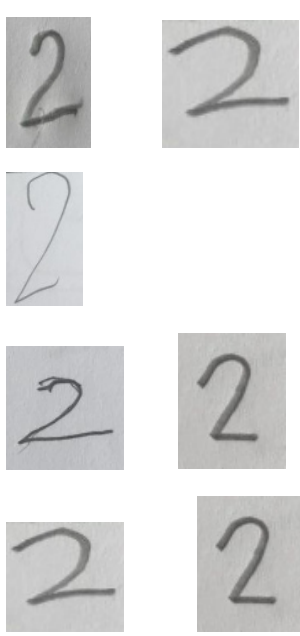

Visual Sample
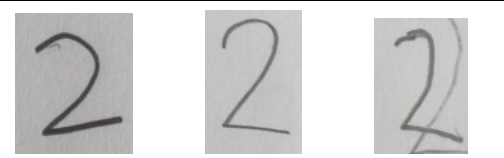

The middle part is less inclined / the middle line is too long
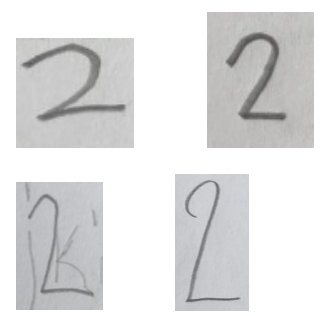

The curve of the top tip is small or narrow
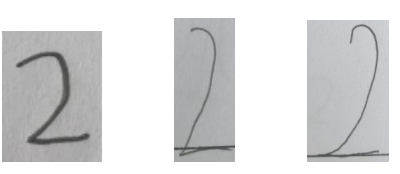

Exaggerating the top curve inward

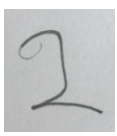

Drawing a sharp top instead of a curve top
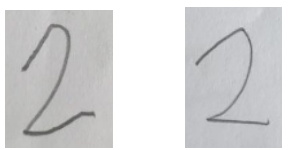

Drawing the bottom line with a curve line instead of a straight line
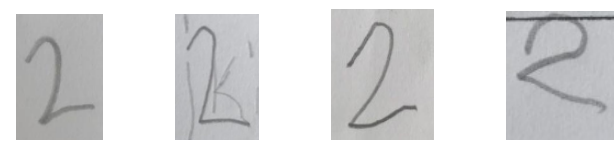

Drawing the same number several times 
Table 3. Types of Common Errors and Sample Visuals from These Errors Which Were Made about the Number "3"

Errors in writing of the number 3
Folding out the bottom and / or the top tip
Upper / downward folding of the bottom tip and / or top tip

Drawing the bottom tip and / or top tip very long/very short

The round parts of the upper and lower parts are not made smooth
Visual Sample
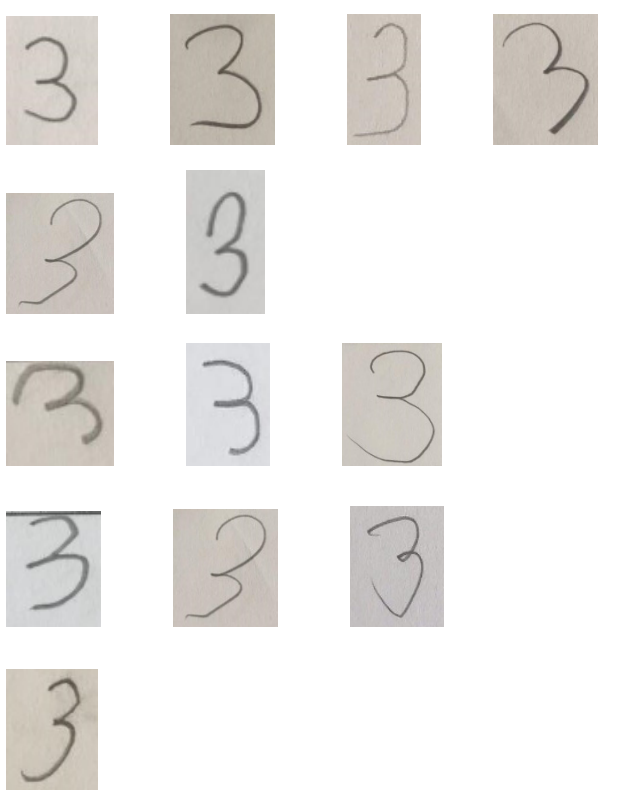

The lower part needs to be larger, but here, the upper and lower parts are the same size or larger than the upper part
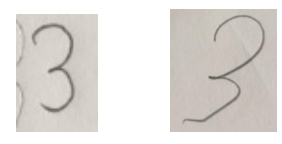

Making the bottom part too big from the top

Making mistakes in the junction of the upper and lower parts
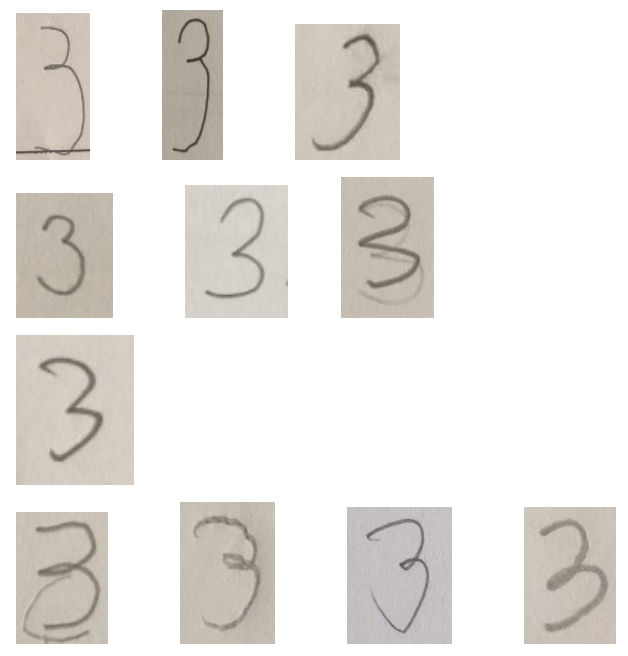

Left / right slanting
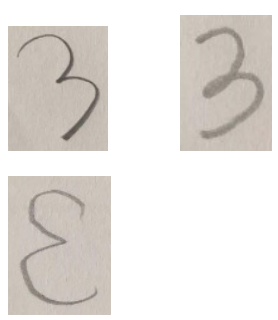

Reverse direction of the number 
Table 4. Types of Common Errors and Sample Visuals from These Errors Which Were Made about the Number "4"

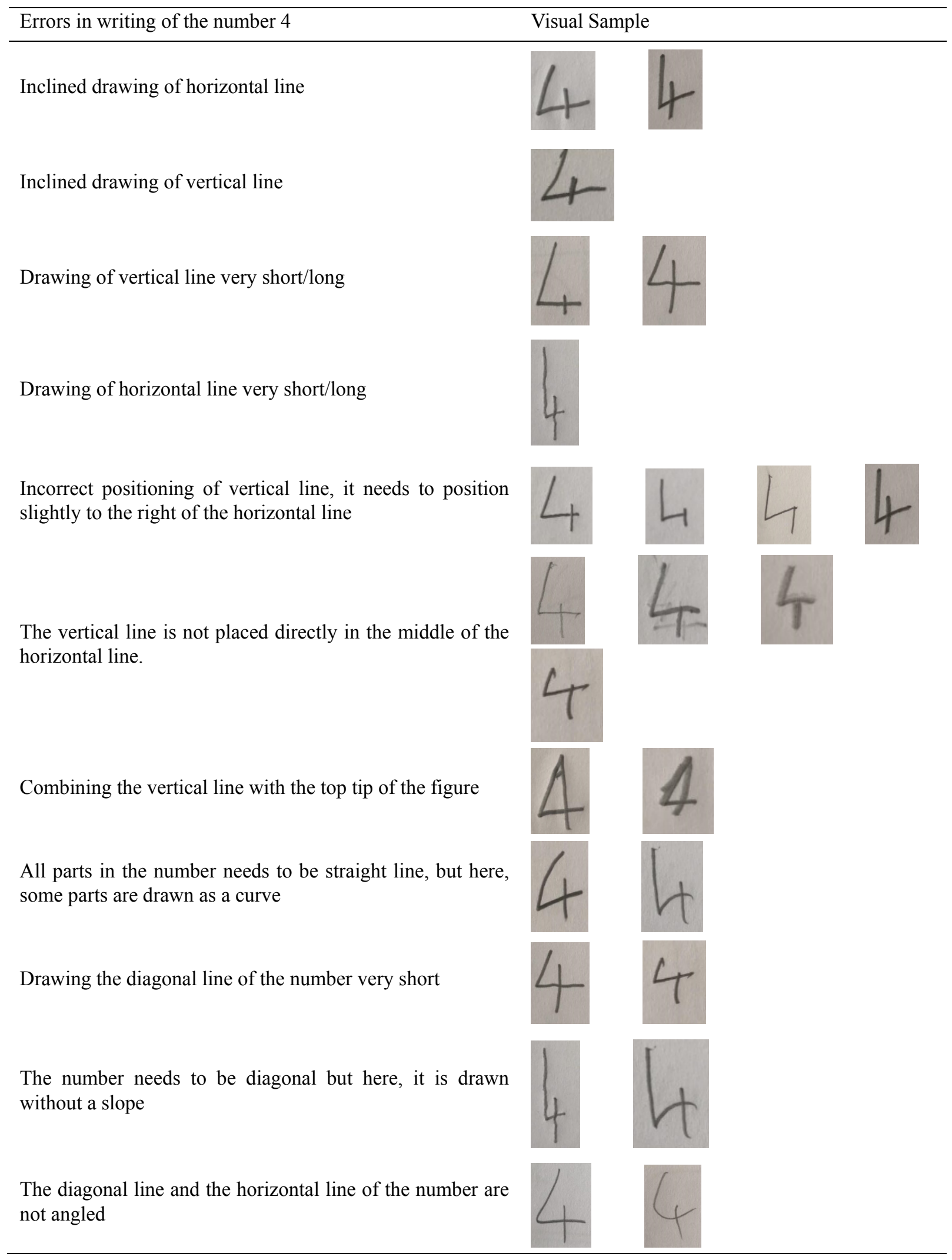


Table 5. Types of Common Errors and Sample Visuals from These Errors Which Were Made about the Number "5"

Errors in writing of the number 5

The height of the round part is very large / very small

The round part is incorrect, its shape is distorted, its bottom tip is long/short

Drawing the horizontal line curved.

Drawing the horizontal line curved instead of straight

Drawing the horizontal line very long/short

A bulge / gap formation in upper left corner

Drawing vertical line very short/long

Drawing the number oblique

The points that need to be sharp are not sharp and using a curved line instead of straight line

Writing the number reversely.
Visual Sample
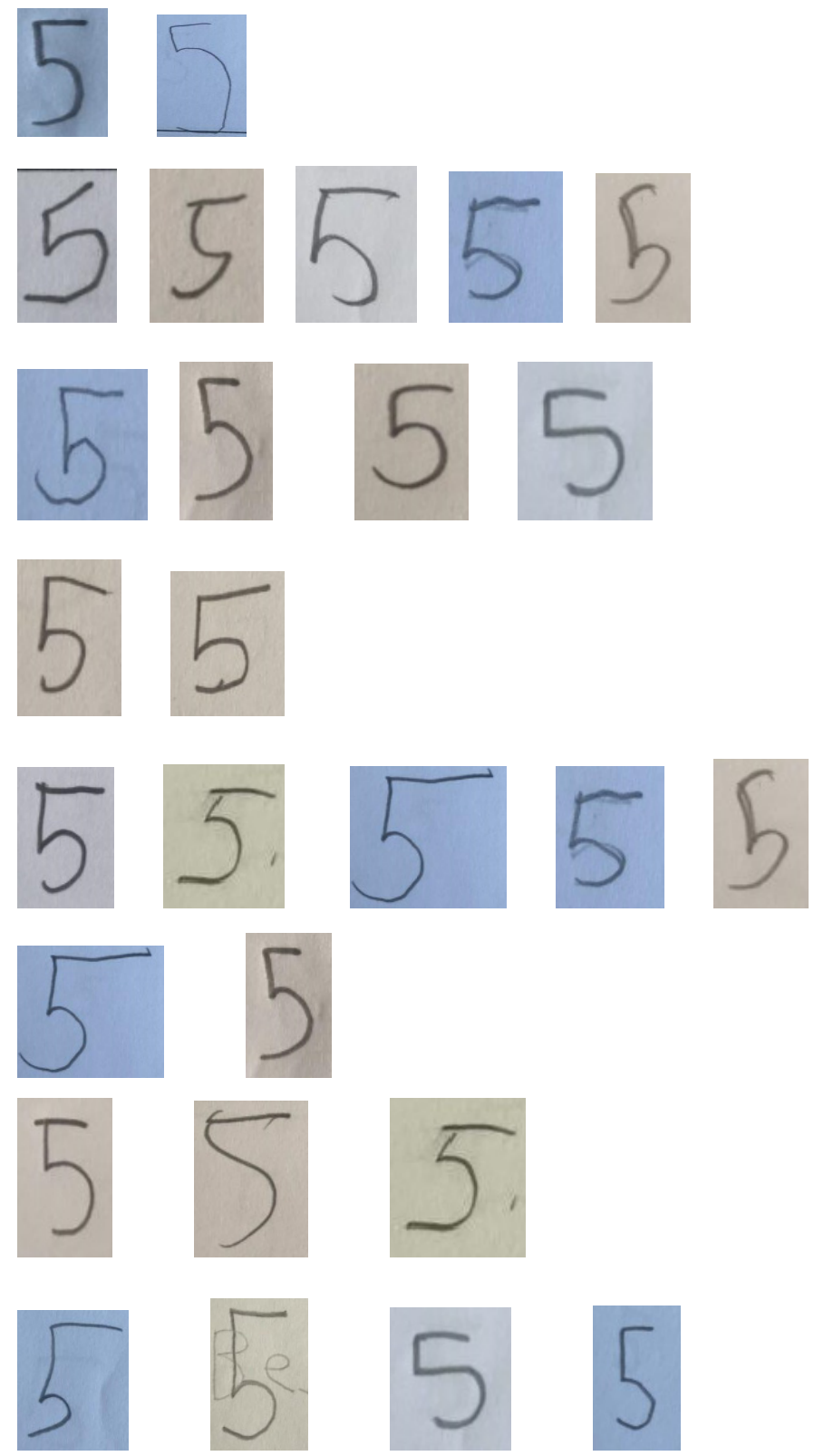
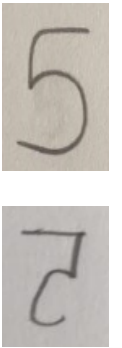
Table 6. Types of Common Errors and Sample Visuals from These Errors Which Were Made about the Number "6"

Errors in writing of the number 6
Drawing the top part curled
Drawing the number like the letter
Not closing round full, leaving
space
Emergencing bulge at the tip point
of the round
The round is not drawn properly
Drawing a straight line while the
number does not have a straight line


Table 7. Types of Common Errors and Sample Visuals from These Errors Which Were Made about the Number "7"

Errors in writing of the number 7
The horizontal lines at the top and/or in the middle and/or
the diagonal lines needs to be straight but here, drawn
oblique.
oblique.

\section{Visual Sample}
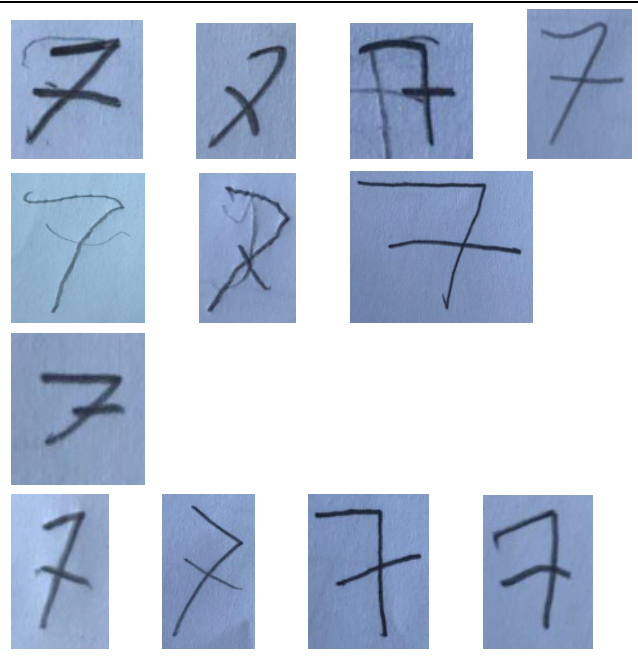

Horizontal lines in the upper and/or in the middle needs to be parallel to the floor, but here, they are drawn inclined.

Drawing the horizontal line in the middle very long/short
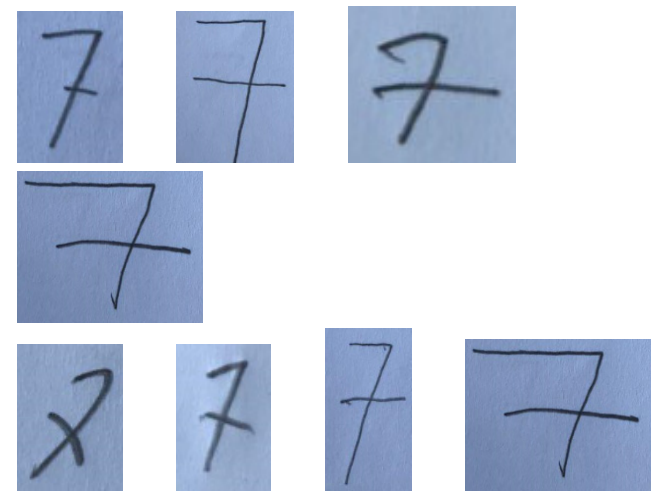

The top right side of the number is drawn with a curved line instead of an angled line.
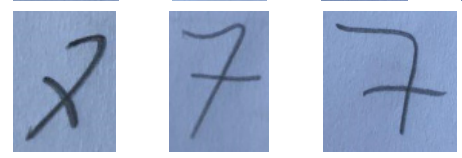

Drawing the diagonal line perpendicular or close to it
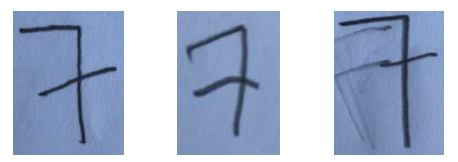

Drawing the diagonal line very long / short

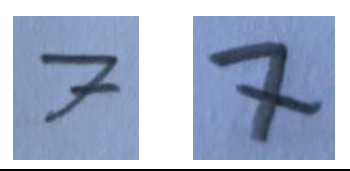


Table 8. Types of Common Errors and Sample Visuals from These Errors Which Were Made about the Number " 8 "

Errors in writing of the number 8
The formation of space/bulge at the junction of the
round

\section{Visual Sample}
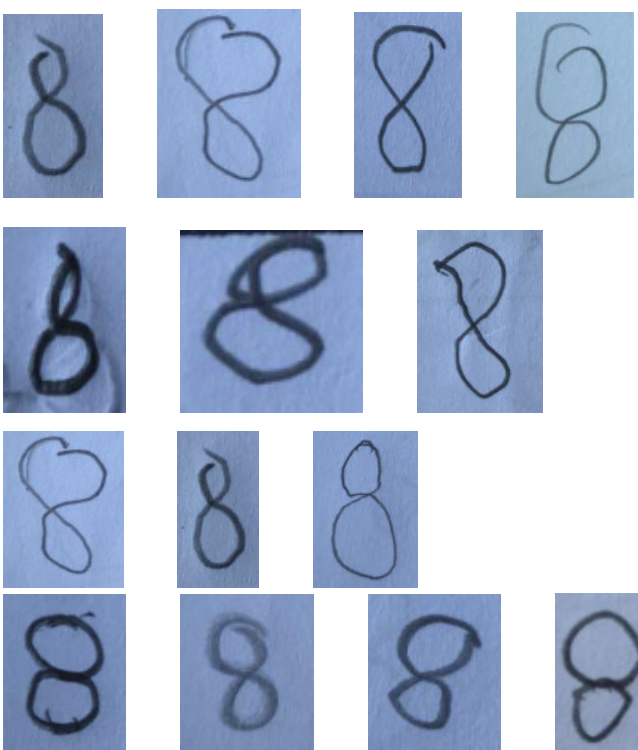
large/small

Drawing the upper part and lower part in the same size or drawing the upper part bigger
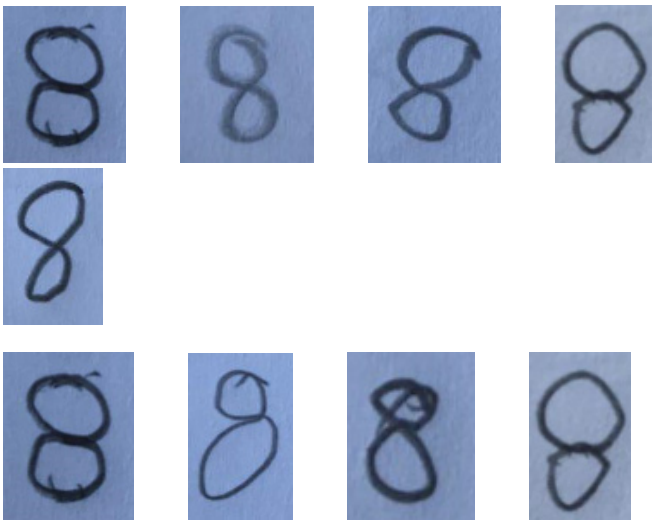
drawing in a row, starting to draw from the wrong place)
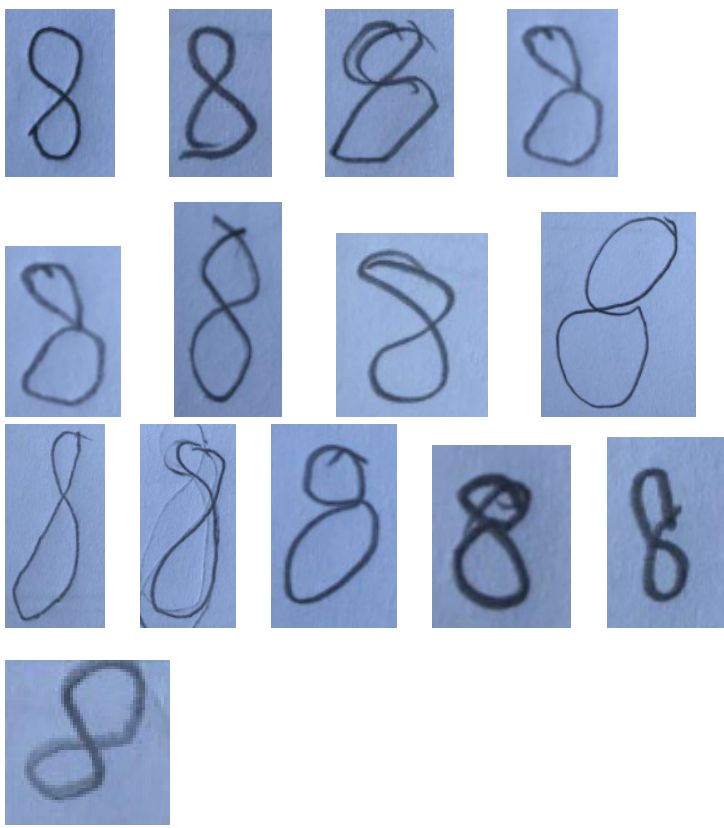
Table 9. Types of Common Errors and Sample Visuals from These Errors Which Were Made about the Number "9"

Errors in writing of the number 9
Making the circle shape improperly

Drawing the tail with a curved line instead of a straight line

Making the lower part curved or angled, drawing the number like the letter g, extending the tip of the number tail very long

Starting to draw from the wrong direction

The formation of a bulge at the end of the circle

Drawing the diagonal line perpendicular or close to it instead of drawing with a curved line

Drawing the bottom part very long/short, making the round part very big/small

Drawing the number reversely
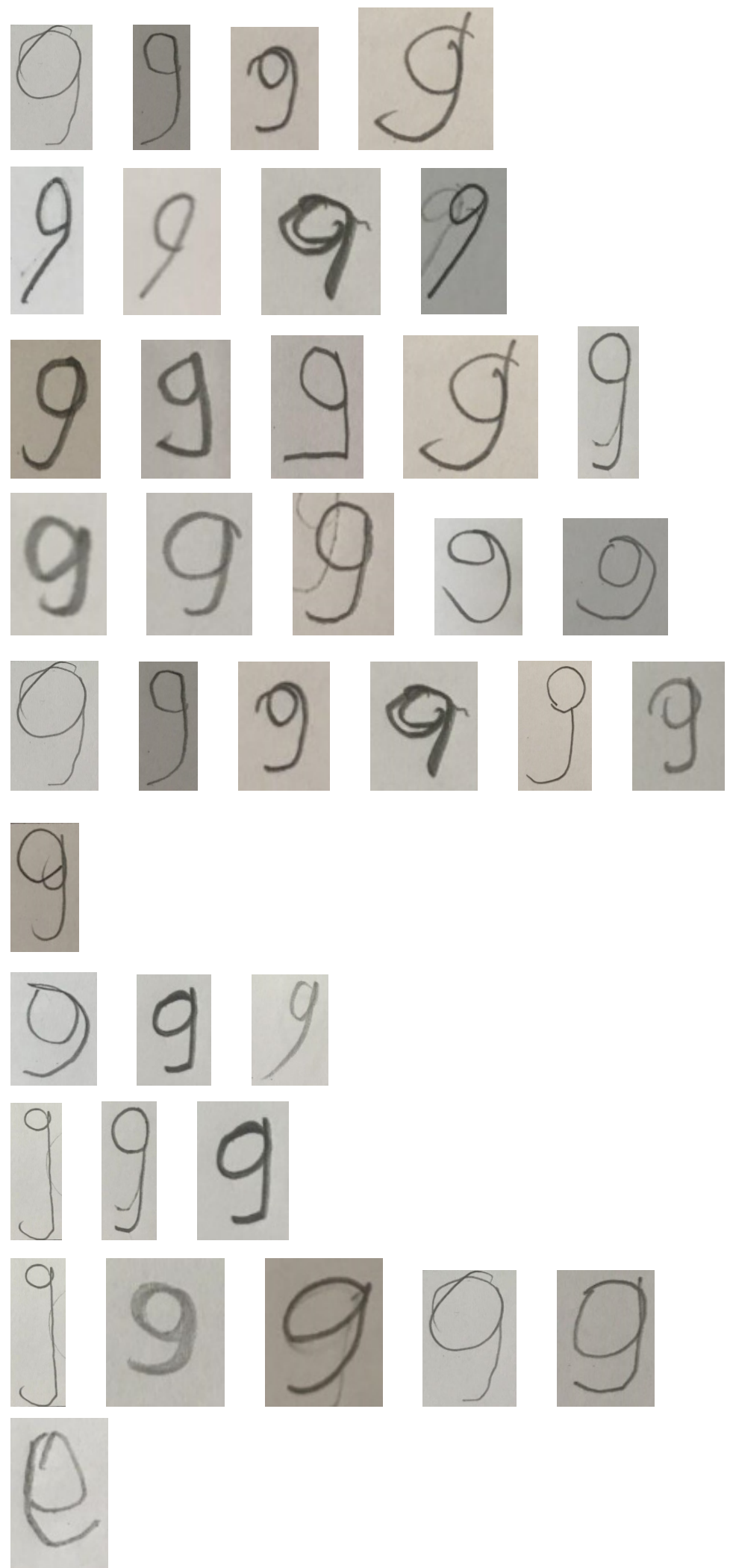
Table 10. Types of Common Errors and Sample Visuals from These Errors Which Were Made about the Number "0"

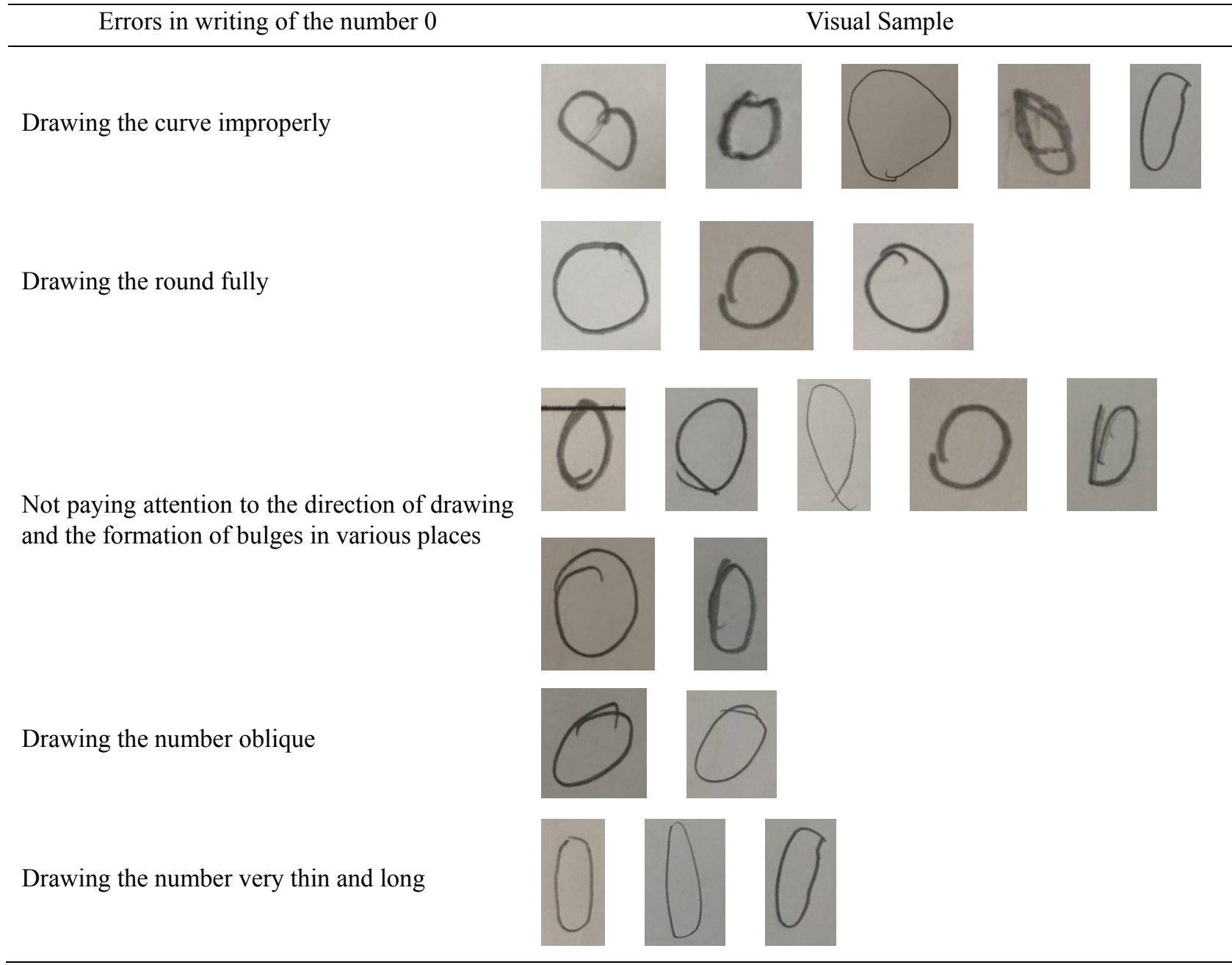

\section{Conclusion and Discussion}

It is expected that students who are at the level of first grade get the acquisitions related to the number writing fully in the process of the first reading-writing. In the studies, it was found that the students studying in higher grades had some deficiencies related to their first reading and writing skills (Akyol \& Sever, 2017; Kusdemir et al., 2018). Therefore, it was aimed to determine the deficiencies related to the number writing of the students in the study. The findings obtained for the study are expressed by giving sample images to the reader for more concrete understanding of the types of errors made for each number and these types of errors. In this section, the situations which are frequently done for each number and common problems in the writing of all numbers are emphasized and discussed in detail. One of the errors in question for all numbers is that the numbers are written in a right or left-hand direction. In fact, the numbers must be written vertically (MEB, 2018b). Although not extensively identified, there are students who make these mistakes. One of the reasons for this type of error is that the ability to write the number upright may not be achieved. This deficiency arises especially in the case of numbers with vertical straight lines resulting from the vertical lines cannot be drawn straightly. It has been determined that the lines that need to be drawn vertically found slanting to the right, slanting to the left, and sometimes parallel to the floor. For this reason, attention should be paid to the ability to draw vertical lines vertically while performing dictation studies in the first reading and writing processes. In numbers without vertical lines, it is thought that the reason why the number is written as oblique is that when the student starts to draw the number, she/he cannot consider the number as a whole. To the degree that the student can visualize the shape of the number as a whole in his mind with all the details, he will be able to write the number more properly. In this context, it will be useful for students to provide activities which create awareness about the specific features of the numbers in their learning process of the number writing. 
When all numbers are considered, it is seen that the lines used in the writing of the numbers are vertical line, horizontal line, diagonal line, curved line and circular line.

When writing the numbers 1, 2, 4, 5, and 7 that contain lines which can be expressed as straight lines such as vertical lines, horizontal lines and diagonal lines, a similar error type has been observed. In this error type, it was seen that students draw straight lines as curvilinear lines. In other words, some students did not acquire the ability to draw the line straight properly. On the other hand, errors that the shape of the curve is not made in the way it needs to be and that there are diagonal places in the line requiring to be curvilinear was seen frequently in the numbers $2,3,5,8$, and 0 which are drawn with curvilinear lines. It was determined that the circle was not exactly rounded, there were angled parts, the round was not fully joined, and there were bulges at the top and bottom were the errors made in the numbers 6 and 9 including circular lines. Regarding these errors, it can be said that the importance of dictation studies emerged again.

When writing studies are performed; it would be beneficial to focus on activities to improve students' skills related to the mentioned situations by taking these types of mistakes into consideration. Teaching processes should be carried out to increase awareness of students about drawing straight line, drawing curved line according to the shape of the number and drawing circular line with full round. However, it is obvious that it is crucial to take individual differences into account in learning when teaching in the process of the number writing. Therefore, activities in these processes need to be diversified as much as possible according to the student (Dogan \& Sahin-Taskin, 2018). At this point, the positive impact of the parent involvement activities on the teaching process should not be underestimated (Dogan \& Sahin-Taskin, 2016).

It is also apparent that one of the common causes of typing errors in all numbers is that students do not use the correct writing direction when writing numbers. In fact, the main theme of the study constitutes whether the students pay attention to the writing directions in the number writing process. However, when the number writings of the students were examined, it was observed that some types of errors were related to failure to comply with the direction of writing the number. It is thought that it would be useful to emphasize the importance of writing directions and its details carefully (Akyol, 2001; Gocer, 2014).

Another important point that needs to be emphasized about the typing errors is that some numbers are reversed. In this study, it was observed that the number of 3,5 and 9 numbers was written in reverse. However, this is the case for every number that is different from the symmetry image according to the vertical axis. There are two reasons for this. One of them may be that the student does not have the necessary knowledge or awareness about the shape of the number. If there are some deficiencies in the student's learning process such as cognitive, emotional or psychomotor, this may have happened. On the other hand, it should be considered whether there is a need for special education for the students who make typing errors (Kodan, 2016). One of the issues that need to be considered in relation to the writing errors in the scope of the study is whether the student is performing these errors due to a difference such as dyslexia. It will be appropriate to conduct a study regarding of the students who are wrong about the number writing reversely.

\section{References}

Akyol, H. (2001). Türkçe İlk okuma-Yazma Öğretimi. Ankara: Gündüz Eğitim ve Yayınc1lık.

Akyol, H., \& Sever, E. (2017). Okuma Yazma Güçlüğü ve Bir Eylem Araştırması: İkinci Sınıf Örneği. Hacettepe Üniversitesi Eğitim Fakültesi Dergisi (Date of publishing: 25.06.2018).

Çelenk, S. (2007). İlkokuma- Yazma Programı ve Öğretimi. Ankara: Maya Akademi Yayınları.

Doğan, M. F., \& Şahin-Taşkın, Ç. (2016). Öğrencilerin Öz-Düzenlemeli Öğrenme Becerilerinin Gelişiminde Anne-Babaların Rolü. International Journal of Curriculum and Instructional Studies, 6(12), 1-18.

Doğan, M. F., \& Şahin-Taşkın, Ç. (2018). Turkish Adaptation of Children's Perceived Use of Self-regulated Learning Inventory. Educational Research and Reviews, 13(10), 375-381.

Göçer, A. (2014). Etkinlik Temelli İlkokuma ve Yazma Öğretimi (2nd ed.). Ankara: Pegem Akademi

Kodan, H. (2016). Yazma Güçlüğü Olan Üçüncü Sınıf Öğrencisinin El Yazısı Okunaklılığının Geliştirilmesi: Eylem Araştırması. Türkiye Sosyal Araştırmalar Dergisi, 2, 523-539.

Kuşdemir, Y., Kurban, H., \& Bulut, P. (2018). Yazma Güçlüğü Yaşayan Bir Öğrenci İle İlgili Eylem Araştırması. Uluslararası Türkçe Edebiyat Kültür Eğitim (TEKE) Dergisi, 7(2), 1190-1209. 
Millı̂ Eğitim Bakanlığı. (2018a). Matematik Dersi Öğretim Programı (İlkokul ve Ortaokul 1, 2, 3, 4, 5, 6, 7 ve 8. Sinıflar). Ankara.

Millî Eğitim Bakanlığı. (2018b). Türkçe Dersi Öğretim Programı (İlkokul ve Ortaokul 1, 2, 3, 4, 5, 6, 7 ve 8. Sinıflar). Ankara.

Stake, R. E. (1995). The art of case study research. Thousand Oaks: Sage Pbc.

Talim \& Terbiye Kurulu Başkanlığı. (2017). TTKB Dik Temel Abece. Yazı Fontu.

Yin, R.K. (2009). Case study methods: design and methods (4th ed.). Thousand Oaks: Sage Pbc.

Yin, R.K. (2012). Applications of Case Study Research. Thousand Oaks: Sage Pbc.

\section{Note}

A part of this research was presented as an oral presentation on 13th International Balkan Education and Science Congress at 06-08 September 2018, Edirne, Turkey. 